\title{
Plutonium plans in limbo
}

Fukushima's economic fallout shutters Britain's Sellafield mixed-oxide facility.

\section{BY EDWIN CARTLIDGE}

$\mathrm{T}$ he Fukushima nuclear disaster, already casting a long shadow over the nuclear industry, has claimed another victim.

Last week, Britain's Nuclear Decommissioning Authority (NDA) announced that it will close a troubled Sellafield facility that is one of only two commercial plants in the world producing mixed oxide nuclear fuel (MOX), after reactor shutdowns in Japan eliminated its only customers for the plutonium-containing fuel. "The reason for this [closure] is directly related to the tragic events in Japan and their ongoing impact on the power markets," says Tony Fountain, the NDA's chief executive. The decision is a setback for the British nuclear industry and leaves the country wondering anew what to do with the world's largest single stockpile of plutonium.

MOX is created by combining uranium with plutonium extracted from spent reactor fuel or recycled from unused nuclear weapons. Proponents say that it provides a way to squeeze more energy out of uranium, reduce the volume of reactor waste, and destroy material that could otherwise be turned back into weapons. MOX accounts for $2 \%$ of the fuel burned in reactors around the world, $80 \%$ of it in France.

Opened in 2001, the Sellafield MOX plant was originally designed to manufacture 560 tonnes of MOX over 10 years. It would have allowed Britain to convert much of its plutonium stockpile, which now stands at 112 tonnes. This was built up over years of reprocessing spent fuel to extract plutonium, which was originally intended for use in fast-breeder reactors.

But technical failures have repeatedly halted MOX production at Sellafield. The plant has produced just 15 tonnes of MOX, at a total cost of $£ 1.4$ billion (US $\$ 2.3$ billion). Its closure leaves the Melox plant in Gard, France, operated by energy company Areva, as the world's only commercial supplier - it has produced about 1,500 tonnes of the fuel since 1995 .

Last year, things were looking up for the Sellafield MOX plant. The NDA, which has owned the plant since 2005, reached an agreement with 10 Japanese electrical utilities that they would buy MOX fuel produced from Japanese plutonium stored at Sellafield. Chubu Electric Power in Nagoya was set

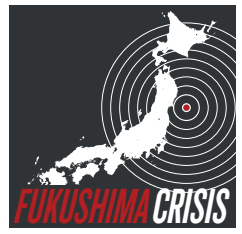

$\rightarrow$ WWW.NATURE. COM/JAPANQUAKE

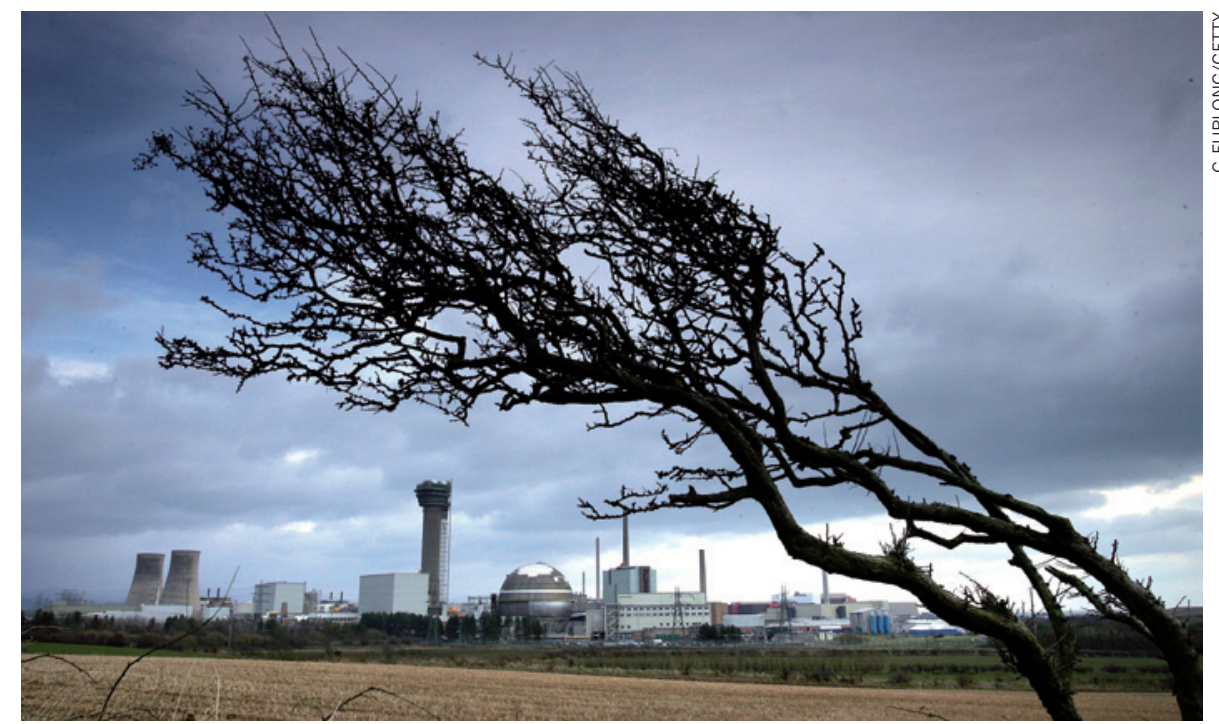

The end of MOX production at Sellafield puts Britain's huge plutonium stockpile in the spotlight.

to pay for upgrades at Sellafield's plant and buy the first consignment of fuel for its Hamaoka power station, and TEPCO, the Tokyo-based utility company that operated the shattered Fukushima Daiichi reactors, would have taken half of all the Japanese fuel produced.

But Sellafield has now lost its customers. In the wake of the nuclear disaster, only 17 of Japan's 54 nuclear reactors are currently operational, TEPCO is under serious financial and political pressure, and Hamaoka remains closed while tsunami protection is improved at the site.

As well as leading to the loss of roughly 600 jobs, the closure will intensify the debate over what to do with Britain's plutonium stockpile. Simply burying the plutonium deep underground would write off the energy that it could generate, and waste an undisclosed sum of money that has already been spent extracting it from spent fuel. But keeping it in indefinite storage is not an option, says Francis Livens, research director of the Dalton Nuclear Institute at the University of Manchester. Over time, plutonium-241 decays to americium-241, which gives off fairly intense gamma radiation that would make handling the stockpile much more difficult.

Consequently, the British government is considering building a brand new MOX plant with a much higher output, with an announcement expected in the autumn. A report produced earlier this year by the University of Oxford's Smith School of Enterprise and the Environment favoured renewed MOX production but estimated the cost of a new plant at $£ 2$ billion to $£ 3$ billion. The government would be "crazy to consider building another MOX plant", says energy-policy analyst Steve Thomas of the University of Greenwich in London. MOX cannot be recycled indefinitely, so "all that reprocessing does is put off the day when we have to dispose of the waste, leaving the problem with people two generations from now".

A spokesman for Areva told Nature that the company does not expect the Fukushima accident to significantly reduce demand for MOX in the long term. He notes that Areva is currently building the United States' first MOX plant, to recycle unwanted plutonium from nuclear weapons, at the Savannah River Site in South Carolina, and that China is also considering its own facility. "This says to us that MOX has a future," he adds.

But the Savannah River facility is hugely over budget, and will produce fuel that will cost about five times as much as conventional nuclear fuel, according to Frank von Hippel of Princeton University, New Jersey, an expert on energy policy and nuclear arms control. And although France is a stronghold of MOX production for now, he adds, its future depends on continued support for nuclear reprocessing from the French government. If the opposition Socialist Party wins next year's presidential election, Areva's position could be weakened, von Hippel argues. "Given the dominance of France in this field," he says, "that would put a question mark over the future of MOX just about everywhere." 